\title{
O MODO DE FAZER RELIGIÃO DAS MULHERES QUE FUNDAM SUAS PRÓPRIAS IGREJAS: FEMINISMO DESCOLONIAL E FEMINISMO COMUNITÁRIO*
}

\author{
Anete Roese**
}

\section{RESUMO}

O texto que segue apresenta uma etnografia do modo de fazer religião das mulheres. Digo 'das' mulheres para dizer daquelas que no contexto religioso contemporâneo no Brasil assumem movimentos protagônicos. Pesquisas anteriores verificaram o fenômeno das muIheres que fundam suas próprias igrejas nas periferias de grandes cidades brasileiras. Esta pesquisa se confronta com o evento de pequenas igrejas criadas por mulheres em uma cidade do interior do Rio Grande do Sul. A fundamentação teórico metodológica se pautou na etnografia feminista, na teoria descolonial e no feminismocomunitário. Os resultados da pesquisa apontam que as mulheres pastoras criam uma religião como resposta a insatisfação, perseguições e tomam a decisão de desertar de um sistema religioso de padrão patriarcal colonial moderno em que não há lugar para mulheres com habilidades de liderança, dons e poderes espirituais. Elas desertam. Neste contexto, elas criam uma ruptura e uma 'fuga' de um sistema religioso opressivo. Seu modo de fazer religião, o como elas fazem, implica, então, a criação de pequenos refúgios - igrejas/religiões/ comunidades de proteção. Seu modo de fazer religião passa pela criação de pequenas comunidades: uma proposta político-espiritual. São comunidades que se reúnem em uma pequena casa alugada ou na própria casa da pastora; criam uma religião em chave doméstica:

* Este texto resume o resultado de pesquisa desenvolvida no estágio pós-doutoral, com o projeto "O modo de fazer religião das mulheres: um estudo etnográfico", realizado na UnB, 2017-2018, no Programa de Pós-Graduação em Direitos Humanos, sob a supervisão da Profa. Dra. Rita Laura Segato. A pesquisa foi teve apoio do CNPq. Agradeço a todas as partes que tornaram possível a realização deste Estágio Pós-Doutoral: ao CNPq; ao Programa de Pós-Graduação em Direitos Humanos (UnB) pela acolhida da proposta; à Profa. Dra. Rita Laura Segato pela Supervisão.

** Doutora em Teologia pela Escola Superior de Teologia (EST). Atualmente realiza estudos de Pós-Doutorado na Universidade de Brasília (UnB) no Programa de Pós-Graduação em Direitos Humanos. Integrante do Grupo de Pesquisa Antropologia e Direitos Humanos. 
domesticam a religião; criam uma religião de pequenas comunidades pautadas no afeto, na proximidade, na gestão vincular. As igrejas/ religiões/comunidades das pastoras serão projetos disfuncionais ao capital, como afirma Rita Segato, não coadunam com o projeto do capital, o projeto dos grandes templos e organizações religiosas. Funcionam como religiosidade doméstica, e a religiosidade doméstica precisa atender as demandas do cotidiano. Estas demandas têm a ver com trabalho/emprego, com saúde/cura, com relações vínculos/afeto/ proximidade vincular-comunidade, cuidado e proteção das pessoas.

Palavras chave: Mulheres. Religião. Igrejas de mulheres. Descolonialidade. Comunidade. Feminismo comunitário.

\section{EL MODO DE HACER RELIGIÓN DE LAS MUJERES QUE FUNDARON SUS PROPIAS IGLESIAS: FEMENISMO DESCOLONIAL Y FEMENIS- MOCOMUNITARIO}

\section{RESUMÉN}

El texto que sigue presenta una etnografía del modo de hacer religión de las mujeres. Digo de las mujeres para decir de aquellas que en el contexto religioso contemporáneo en Brasil asumen movimientos protagónicos. Investigaciones anteriores verificaron el fenómeno de las mujeres que fundan sus propias iglesias en las periferias de grandes ciudades brasileñas. Esta investigación se enfrenta al evento de pequeñas iglesias creadas por mujeres en una ciudad del interior de Rio Grande do Sul. La fundamentación teórica metodológica se ha basado en la etnografía feminista, en la teoría descolonial y en el feminismo comunitario. Los resultados de la investigación apuntan que las mujeres pastoras crean una religión como respuesta a la insatisfacción, persecuciones y toman la decisión de desertar de un sistema religioso de patrón patriarcal colonial moderno en el que no hay lugar para mujeres con habilidades de liderazgo, dones y poderes espirituales. Se desertan. En este contexto, crean una ruptura y una "fuga" de un sistema religioso opresivo. Su modo de hacer religión, cómo ellas hacen, implica, entonces, la creación de pequeños refugios - iglesias/religiones/comunidades de protección. Su modo de hacer religión pasa por la creación de pequeñas comunidades: una propuesta político-espiritual. Son comunidades que se reúnen en una pequeña casa alquilada o en la propia casa de la pastora; crean una religión dominante doméstica: domestican la religión; crean una religión de pequeñas comunidades pautadas en el afecto, en la proxi- 
midad, en la gestión vinculante. Las iglesias/religiones/comunidades de las pastoras serán proyectos disfuncionales al capital, como afirma Rita Segato, no concatan con el proyecto del capital, el proyecto de los grandes templos y organizaciones religiosas. Funcionan como religiosidad doméstica, y la religiosidad doméstica necesita atender las demandas de lo cotidiano. Estas demandas tienen que ver con trabajo/empleo, con salud/curación, con relaciones vínculos/afecto / proximidad vincular-comunidad, cuidado y protección de las personas. Palabras clave: Mujeres. Religión. Iglesias de mujeres. Descolonialidad. Comunidad. Feminismo comunitario.

\title{
THE WAY OF MAKING RELIGION OF THE WOMEN WHO FOUND THEIR OWN CHURCHES: DESCOLONIAL FEMINISM AND COMMU- NITARIAN FEMINISM
}

\begin{abstract}
The following text presents an ethnography of women's religion. I say 'of' women to speak of those who in the contemporary religious context in Brazil assume protagonic movements. Previous researches have verified the phenomenon of women who found their own churches in the periferies of large Brazilian cities. This research is confronted with the event of small churches created by women in a city in the countryside of Rio Grande do Sul. The theoretical methodological foundation was based on feminist ethnography, descolonial theory and communitarian feminism. The survey results point out that pastoral women create a religion as a response to dissatisfaction, persecution and the decision to defect from a religious system of modern colonial patriarchal pattern in which there is no place for women with leadership skills, gifts and spiritual powers. They desert. In this context, they create a rupture and an 'escape' from an oppressive religious system. Their way of making religion, as they do, implies, then, the creation of small refuges - protection churches/religions/communities. Their way of making religion involves the creation of small communities: a political-spiritual proposal. They are communities that congregate in a small rented house or in the female pastor's own house; they create religion in a domestic key: they domesticate religion; they create religion of small communities based on affection, proximity, and binding management. The female pastor's churches/religions/communities will be dysfunctional capital projects, as Rita Segato asserts, they do not co-exist with the capital
\end{abstract}


project, the design of large temples and religious organizations. They function as domestic religiosity, and domestic religiosity needs to meet the demands of daily life. These demands have to do with work/ employment, with health/healing, with bonds/affection/proximity bonding-community, care and protection of people.

Keywords: Women. Religion. Churches of women. Descoloniality. Community. Communitarian feminism.

\section{INTRODUÇÃO}

Faço ciências da religião ou teologia por demanda, parafraseando Rita Segato ao se referir a antropologia e o fazer antropologia por demanda. Afinal, há interpelações do contexto atual que me chegam como demandas a serem pesquisadas, conhecidas. As pastoras e seu modo de fazer religião são a demanda que assumo aqui como desafio para a ciência, a religião, o mundo.

O texto que segue apresenta o caminho que tratou de perscrutar a experiência de mulheres no modo de fazer religião neste momento da história, no Brasil, no século XXI. Tempo em que o poder religioso de ordem e sistema colonial moderno parece revigorar, ou seja, grandes empreendimentos religiosos se estabelecem, o poder sacerdotal se concentra nas mãos de poucos líderes, homens de negócios e bens. Ao poder religioso se vincula com nova força o poder político em um sistema de trocas, alianças e benefícios políticos e econômicos. Simultaneamente, outras dinâmicas religiosas surgem nas brechas deste sistema dominante. 'A olho nu não é possível ver, nem crer que há outras formas de religião, religiosidade e espiritualidade em processo, pois não são tão visíveis para a ciência sem uma pesquisa empírica e uma hermenêutica crítica que seja hábil em reconhecer os protagonismos das mulheres no âmbito religioso no ocidente cristão atual. Em princípio, poderíamos concluir que uma força renovada do cristianismo patriarcal se r/estabelece no ocidente - como se pode observar no sistema político por meio das alianças políticas com grupos religiosos ou na mídia com o poder que tem grupos detentores de espaços e canais para difusão de suas perspectivas religiosas. Aqui nos perguntamos sobre o que escapa a isso. O que escapa da homogeneidade dos grandes discursos e dos grandes templos. É necessário verificar qual é a ordem das mulheres 
para ultrapassar a dominação patriarcal das religiões; qual a relação que elas estabelecem hoje com as religiões tradicionais; analisar o conservadorismo patriarcal evangélico que avança para o campo político ampliando seu espaço de domínio e seu moralismo.

A convicção que temos a partir da observação das rupturas protagonizadas pelas mulheres, verificadas sobremaneira neste $3^{\circ}$ milênio, é que as mulheres estão pouco a pouco assumindo a sua autonomia, criando com autenticidade espaços e caminhos alternativos aos das religiões hegemônicas, suas estruturas e discursos, ainda que estes novos espaços e caminhos que vem sendo elaborados por elas nem sempre prescindam totalmente dos conhecimentos adquiridos naqueles.

\section{CAMINHOS DE PESQUISA}

A identificação de dezenas, já podemos falar em centenas de pequenas igrejas fundadas por mulheres já aparece em pesquisas acadêmicas feitas no Brasil (Janine SILVA, 2010; Rosane GUGLIELMONI, 2015). Aqui coloco a ênfase no "modo de fazer" religião das mulheres que fundam suas próprias religiões (neste caso a afininidade com o cristianismo é preponderante), e as perguntas que fundamentam a pesquisa estão relacionadas com o funcionamento, na organização do espaço religioso que elas comandam.

Me valho da etnografia feminista - que parte da etnografia crítica contemporânea e reelabora concepções desta com a finalidade de enfrentar a naturalização de instâncias culturais e dar visibilidade à experiência de mulheres, além de "reintroduzir a perspectiva histórica no estudo da condição de gênero localizada"" (SALGADO, 2012, p. 230, tradução livre).

Os temas nos quais pesquisas atentas à questões de gênero e religião colocarão sua atenção estão relacionados à verificação do mundo das mulheres e suas necessidades específicas, seu modo de fazer e organizar a vida. Neste específico, é importante verificar o uso que as mulheres fazem da religião. A partir da observação da relação das mulheres com a religião, de estudos e acompanhamento de pesquisas anteriores sobre o tema levantamos a suspeita de que a relação das

Reintroducir la perspectiva histórica en el estudio de la condición de género localizada. 
mulheres com a religião está estreitamente vinculada com a vida cotidiana, seja suas dificuldades ou suas alegrias. É muito evidente que o modo de fazer religião das mulheres, fora do domínio colonial patriarcal está intimamente vinculado com a casa, o mundo doméstico, vida real. Sua maneira trata de integrar a religião à vida de modo a compor uma visão integradora, que as mulheres aprenderam sobre si e o mundo. Ou seja, para as mulheres a religião precisa responder à vida cotidiana e precisa caber na dinâmica da vida como um todo. Saúde, trabalho, cuidado de pessoas, todas as conquistas e necessidades da vida precisam caber na prática religiosa, bem como a religião precisa caber na vida ordinária. Não há cisão. Não há, para elas, uma separação radical entre a religião e as demais dimensões da vida. Elas precisam e fazem da religião algo para cuidar de si, das suas filhas e filhos, das pessoas da família, de amigas. Religião não é um negócio, nem o modo de exercer poder sobre outras pessoas.

A criação ou fundação de igrejas por mulheres indica para isto. Há um desacordo das mulheres para com o modo anterior de fazer e ter religião, e uma crítica subliminar à tradição patriarcal. Um êxodo de muIheres em busca de outras formas de vida religiosa, uma desobediência às ordens, aos estatutos teológicos e rituais das tradições hegemônicas estabelecidas no contexto.

A etnografia feminista, decisiva para a pesquisa empírica empreendida sobre as mulheres e a criação de espaços religiosos na atualidade, segue os passos fundamentais da etnografia crítica e importa aspectos centrais para as teorias de gênero a fim de possibilitar o acesso à vida das mulheres e garantir o alcance da dimensão subjetiva. $\mathrm{Na}$ observação é preciso ter entendimento claro sobre o que interessa no contexto. Aqui, trata-se ter conhecimento e habilidade no trato das teorias de gênero, as questões fundamentais para as mulheres no que diz respeito ao lugar que ocupam e desejam ocupar na religião (desejo de autonomia ou não, experiência atual e anterior), a observação de elementos que dizem respeito à vida cotidiana - fazeres, desejos, relações.... Intersubjetividade, estabelecimento de confiança/empatia por parte da pesquisadora. Sobre a descrição - o que se observa e o que se descreve está relacionado com a organização social de gênero, pois 
denotará as diferentes experiências de mulheres e homens. A descrição neste caso deve cumprir o papel de apresentar e desvendar os rasgos de gênero que se apresentam no campo observado. Neste sentido, a descrição feminista reconstrói o apresentado, conceitua e interroga a ordem estabelecida que condiciona uma organização de gênero. Com esta finalidade, diz Salgado:

[...] descrever se torna o exercício de desvendar o conjunto de inter-relações que dão sentido e dotam o observado de significado. Descrever é, em grande medida, identificar, desconstruir e elaborar interpretações que, na busca de sentido, apelam para alguns dos procedimentos centrais da epistemologia e da metodologia feminista: visualização, desnaturalização e historicização (SALGADO, 2014, p. 232, tradução livre) $)^{2}$.

A linguagem: trata-se de dar voz às mulheres, descrever suas narrativas de si, como se compreendem a si mesmas, como definem o lugar que ocupam em seu contexto religioso, no mundo, sua cosmovisão; verifica-se as metáforas que usam para falar do lugar que ocupam na sociedade, no mundo, a que sentimentos se referem para se referir ao lugar que ocupam ou aos lugares que não ocupam e não puderam ocupar. A escrita e a narrativa etnográfica trata da implicação da pesquisadora na situação narrada e sua narrativa. Esta escrita e narrativa implica no enfrentamento da própria cultura da pesquisadora e da epistemologia androcêntrica que atravessa a ciência ocidental. A revalorização da história: aqui uma revisão e releitura da história é importante pois implica em um estudo dos processos e mudanças desde o ponto de vista da mulher. Uma nova visão deve levar em conta uma das perspectivas feministas centrais que trata de superar o essencialismo que acompanha a noção de cultura. A atualização do trabalho de campo: implica em revisão das metodologias de investigação e a consequente abertura interdisciplinar

[...] describir se convierte en el ejercicio de desentrañar el conjunto de interrelaciones que le dan sentido y dotan de significación a lo observado. Describir es, en buena medida, identificar, deconstruir y elaborar interpretaciones que, en la búsqueda de sentido, apelan a algunos de los procedimientos centrales de la epistemología y la metodología feminista: la visibilización, la desnaturalización y la historización. 
para enfrentar antigos paradigmas dualistas como o público e o privado. E uso de novas tecnologias: implica em recorrer as fontes tecnológicas disponíveis hoje que podem dinamizar a pesquisa e ajudar no alcance e na captura de mais fontes.

Para Rita Segato, a tarefa da antropóloga no labor da pesquisa empírica consiste em interpretar os símbolos que compõe o texto religioso (transcrição do texto atuado), esclarecendo o que querem dizer sobre uma experiência social, histórica ou étnica; "essa análise tem em vista as noções, valores e interesses que estão por trás da opção de um grupo por uma nova adesão religiosa". Ademais, no discurso religioso aparecem as declarações "relativas ao ambiente social e natural, bem como sobre noções fundamentais que guiam suas vidas", "a interpretação deste discurso deveria revelar-nos 'o dito' (Clifford GEERTZ, 1973) desta enunciação simbólica” (Rita SEGATO, 2007, p. 204).

Encruzilhada do Sul, uma cidade do interior do Rio Grande do Sul, a $200 \mathrm{~km}$ ao sul da capital Porto Alegre, com 25 mil habitantes, foi a cidade com a qual me deparei com surpresa ao saber que também lá já haviam mulheres fundando suas próprias igrejas. Outras pesquisas sobre o tema já se deram em grandes centros urbanos como Belo Horizonte e Rio de Janeiro, e a identificação do mesmo fenômeno em uma pequena cidade do sul do país dá sinal de que o fenômeno já ultrapassou as capitais e religiões metropolitanas. Optei por circunscrever a pesquisa empírica a duas igrejas identificadas nesta cidade a partir das informações que conseguimos obter. Não obstante, o contexto que se apresentava à medida em que eu ia buscando, foi desde logo se mostrando desafiador e instigante para uma pesquisa mais ampla. As visitas a bairros e casas da cidade, indicadas por alguma fonte, para que localizássemos igrejas de mulheres, foi nos (no plural, pois eu estava sendo acompanhada por Sandra, moradora da cidade) levando a casas de santo/terreiros/centros religiosos das religiões de matriz africana liderados por mulheres; outras indicações nos apontavam casas de benzedeiras/curandeiras, e uma outra ainda, nos levou à casa de uma mulher que era pastora com grande atuação em uma pequena igreja na qual trabalhava junto com homens e era liderada por um homem e por isso foram excluídas da pesquisa. Esta última era interessante também, pois indicava claramente para o poder e capacidade de liderança daquela mulher pastora. 
A fundamentação teórica da pesquisa centrou sua base em pesquisas anteriores sobre o tema, obras da supervisora da pesquisa a antropóloga Dra. Rita Laura Segato e a perspectiva da des/colonização, uma importante obra sobre feminismo comunitário e teorias de gênero e feminismo.

\section{GÊNERO, PATRIARCADO, FEMINISMO}

O feminismocomunitário retoma os conceitos básicos do feminismo fazendo sua análise crítica, propondo uma ruptura epistemológica com o feminismo ocidental, situando os conceitos no contexto de sua compreensão desde Abya Yala. Considerando a realidade brasileira, com sua avalanche religiosa e política conservadora, com o nefasto discurso da chamada "ideologia de gênero" que afronta as conquistas feministas para as mulheres e a população LGBTT é urgente atualizar o uso das categorias 'gênero' e ‘patriarcado'. O feminismocomunitário dá um passo importante neste sentido ao afirmar que 'gênero' não dá conta de explicar todas as opressões. Afinal, as relações de gênero são apenas um dos níveis ou modalidades de relações sociais das quais participamos.

Gênero é uma prisão criada sobre os corpos. "O gênero, para o feminismo comunitário, é a prisão, que o patriarcado constrói sobre os corpos dos homens e sobre os corpos das mulheres" (Julieta PAREDES; Adriana GUZMÁN, 2014, p. 74, tradução livre)3. Como categoria analítica 'gênero' é um conceito de denúncia criado no feminismo, uma categoria política que deflagra as relações de poder opressivo, violento imposto sobre os corpos e a vida de mulheres e homens. A despolitização deste conceito é um grave erro que hoje se infiltrou inclusive no feminismo. Tal como no marxismo, onde se denuncia as relações de exploração de classes e es propõe o fim das relações de classes, as feministascomunitárias propõe o fim das relações de gênero, para que não hajam relações de gênero porque não há possibilidade de reforma-las, de buscar igualdade ou equidade neste campo. Ou seja, elas afirmam sua luta pelo desaparecimento dos gêneros (Julieta PAREDES; Adriana GUZMÁN, 2014). Segundo Rita Segato, "gênero é... a forma ou configuração histó-

3 El género, para el Feminismocomunitario, es la cárcel, que el patriarcado construye sobre los cuerpos de los hombres y sobre los cuerpos de las mujeres. 
rica elementar de todo poder na espécie e, portanto, de toda violência, já que todo poder é resultante de uma expropriação inevitavelmente violenta" (Rita SEGATO, 2016, p. 19).

O conceito 'patriarcado' se torna eixo central no feminismo como categoria analítica de todo um sistema de opressão das mulheres, que serão as súditas do pater/pai de família, do homem que domina a política, a economia, a religião monoteísta, Deus será homem e o homem será comparado e regerá como divindade. O sistema patriarcal é amplamente conhecido em várias culturas e religiões de monoteísmo masculino, mesmo antes das colonizações modernas, a exemplo das tradições hebreia/judaica, cristã, islâmica. Uma das versões mais importantes do monoteísmo patriarcal afirma que o corpo original do ser humano criado por Deus era masculino e sem pecado, enquanto o corpo da mulher foi criado em segundo lugar e foi o primeiro a pecar (livro de Gênesis, capítulo 1-2, Texto sagrado judaico e cristão). As feministas comunitárias chamam a atenção e redefinem o conceito patriarcado dado o reducionismo no âmbito do próprio feminismo de características eurocêntricas, o qual restringiu a explica-lo como um sistema de opressão de homens sobre mulheres.

Para as feministas comunitárias 'patriarcado' é "o sistema de todas as opressões, todas as explorações, todas as violências e discriminações que vive toda a humanidade (mulheres, homens e pessoas intersexuais) e a natureza, historicamente construídas, sobre o corpo sexuado das mulheres"4 (Julieta PAREDES; Adriana GUZMÁN, 2014, p. 76, tradução livre). Se trata de um complexo sistema de múltiplas opressões, o mais duradouro conhecido e o mais letal, impregna palavras, discursos, gestos, hábitos, leis, símbolos, perpassa a economia, a política, a educação a religião. Afeta distintamente diferentes grupos sociais com maior ou menor intensidade. Dentre estes grupos as mulheres estão entre o grupo que mais sofre as consequências deste perverso sistema de exclusão, preconceito e opressão. No feminismocomunitário se reconhece um patriarcado ancestral, anterior a intrusão colonizadora em Abya Yala.

4 El Patriarcado es, el sistema de todas Jos opresiones, todas las explotaciones, todas las violencias, y discriminaciones que vive, toda la humanidad (mlljeres y personas imersexuales) y la naturaleza, históricamente construidas, sobre el cuerpo sexuado de fas mujeres. 
Para recuperar a memória do patriarcado em Abya Yala é necessário recorrer a uma "memória ampla", e verificar a contemporaneidade das sociedades no tempo do calendário europeu de 1492, quando em Abya Yala o calendário marcava o ano 5521. O fato é que não se trata do patriarcado europeu, afinal, segundo Julieta Paredes e Adriana Guzmán (2014), não vamos explicar o mundo todo a partir da Europa.

A situação das mulheres na Europa ao redor do ano 1492 eram as da inquisição. Durante séculos foram perseguidas e seu conhecimento foi destruído, seus direitos e sua moral foram aniquilados. Não tinham direito a posse de terras, não tinham poder diante de seus maridos e não tinham acesso ao manejo dos ritos religiosos. A Europa estava baixo um poder feudal e assolada por fome, peste, guerras.

Um mundo muito diferente era nosso em Abya Yala, as mulheres tinham o direito de desembarcar, os homens herdaram uma mulher tocapu metade tocapu ou as mulheres não passavam fome se um homem as deixasse, olho! mas eles não herdaram a mesma quantidade de terra. As mulheres manejavam o remédio de seus corpos e dos wawas, meninas e meninos, ninguém os perseguia, nem matavam para lidar com essa sabedoria. Nestes territórios as mulheres eram autoridades políticas e militares, eram curacas e, claro, manejavam os ritos da lua, ritos que não eram de homens (Julieta PAREDES; Adriana GUZMÁN, 2014, p. 80, tradução livre)5.

Muito claramente Julieta Paredes e Adriana Guzmán sustentam e demonstram a existência de um patriarcado anterior a intrusão colonizadora. $\mathrm{O}$ encontro de dois sistemas diferentes em intensidade, mas ambos patriarcais levam ao que elas denominam de "entronque patriarcal". É o encontro de dois sistemas patriarcais, por onde se dão "combinações, alianças, cumplicidades entre homens colonizadores invasores e

Mundo muy distinto eran los nuestros en Abya Yala, las mujeres tenían derecho a la tierra, los hombres heredaban un tocapu las mujeres medio tocapu o sea las mujeres no se morían de hambre si un hombre las abandonaba ¡ojo! pero no heredaban igual cantidad de tierra. Las mujeres manejaban la medicina de sus cuerpos y de las wawas, niñas y niños, nadie las perseguía, ni mataban por manejar esta sabiduría. En estos territorios las mujeres eran autoridades políticas y militares, eran curacas y por supuesto que manejaban los ritos de la luna, ritos que no eran de los hombres. 
homens indígenas nativos de nossos povos uma articulação desigual entre homens, mas uma articulação cúmplice contra as mulheres, que confabulou uma nova realidade patriarcal que é o que vivemos até hoje" (Julieta PAREDES; Adriana GUZMÁN, 2014, p. 83, tradução livre) ${ }^{6}$.

Em La guerra contra las mujeres, Rita Segato se propõe a fazer uma etnografia do poder - na sua forma fundante e permanente o patriarcado. Para a autora, o patriarcado é o cimento, o pilar, a pedagogia de todo poder. "O mandato de masculinidade se coloca como a primeira e permanente pedagogia de expropriação de valor e conseguinte dominação"7 (Rita SEGATO, 2016, p. 16, tradução livre). Já não é suficiente falar de desigualdade, o problema hoje é de 'senhorio'/“dueñidad”. É difícil etnografar, decifrar o patriarcado, com seu pacto de silêncio. Mais bem podemos cartografar seus efeitos.

Rita Segato se pergunta por que o projeto histórico dos donos Ihes é tão caro, a ponto de insistirem na reinserção do patriarcalismo usando de um fanatismo militante. Podemos verificar um extraordinário empenho no campo de 'gênero' por parte da nova direita representada pelas facções mais conservadoras de todas as igrejas, representantes do empresariado extrativista recalcitrante atuado no agronegócio e nas mineradoras... a ponto de destruírem qualquer intento de justiça social, igualdade, destruírem qualquer ameaça ao senhorio (Rita SEGATO, 2016).

A “expressão patriarcal-colonial-modernidade descreve adequadamente a prioridade do patriarcado como apropriador do corpo das mulheres e deste como primeira colônia"8 (Rita SEGATO, 2016, p. 19, tradução livre). Rita defende que o "patriarcado, ou a relação de gênero baseada na desigualdade, é a estrutura política mais arcaica e permanente da humanidade"9 (Rita SEGATO, 2016, p. 18, tradução livre). É

6 ... combinaciones, las alianzas, las complicidades entre hombres invasores colonizadores y hombres indígenas originarios de nuestros pueblos una articulación desigual entre hombres, pero articulación cómplice contra las mujeres, que confabula una nueva realidad patriarcal que es la que vivimos hasta el día de hoy.

7 el mandato de masculinidad como primera y permanente pedagogía de expropiación de valor y consiguiente dominación.

8 La expresión patriarcal-colonial-modernidad describe adecuadamente la prioridad del patriarcado como apropiador del cuerpo de las mujeres y de éste como primera colonia.

9 el patriarcado, o relación de género basada en la desigualdad, es la estructura política más arcaica y permanente de la humanidad. 
agravada na conquista e colonização, tornando-se altamente letal, com uso de violência extrema contra indivíduos e grupos. Mesmo a violência sexual, cuja finalidade não é de ordem libidinal - para satisfação de um desejo sexual, mas da ordem do poder, da dominação. Afinal, é "mediante este tipo de violência que o poder se expressa, se exibe, se consolida..." (Rita SEGATO, 2016, p. 18, tradução livre).

O patriarcado é um processo de conquista permanente, de "conquistualidade". Rita Segato cria o termo "conquistualidade" por entender que expressa melhor que colonialidade o fato de que, com base nos eventos violentos em grande escala, e também pela crueldade constante presente nos pequenos eventos, que a conquista nunca terminou. A compreensão de que a conquista nunca acabou é uma constatação de suma importância, apresentada por Aníbal Quijano, no sentido de ajudar a compreender a necessidade do sistema patriarcal de manter de modo ininterrupto a dominação, o senhorio, com o uso da violência - o método mais eficaz e cruel de manter o poder.

O que mascara e mantém o patriarcado com a força sempre renovada é, de acordo com Rita Segato, este "caráter binário da estrutura que torna a esfera pública englobante, totalizante, por cima de seu outro residual: o domínio privado, pessoal; quer dizer, a relação entre vida política e vida extra-política""11 (Rita SEGATO, 2016, p. 23, tradução livre). A organização binária é opressiva e violenta, pois sua estrutura hierárquica apresenta um fosso imenso de diferença entre o que se considera central, universalizado e o seu oposto, o particular, marginal, minoria. É necessário criar a erosão da estrutura binarista, do binarismo da matriz colonial moderna - cujos binarismos vão muito além do de gênero. É importante deixar de depositar toda fé no Estado. Na estrutura binária verdades carregam valores universais que, por sua vez, segundo o imaginário, provém da figura masculina e seus outros, concebidos como dotados de importância particular, marginal, minoritária. (Rita SEGATO, 2016).

10 mediante este tipo de violencia el poder se expresa, se exhibe y se consolida...

1 el carácter binario de la estructura que torna la Esfera Pública englobante, totalizante, por encima de su otro residual: el dominio privado, personal; es decir, la relación entre vida política y vida extra-política. 


\section{CHAVES DE SENTIDO PARA UMA COMPREENSÃO DO MODO DE FAZER RELIGIÃO DAS MULHERES}

Na sequência apresento o encontro com as igrejas das mulheres e seus possíveis sentidos de existência e criação. Identifiquei chaves no processo hermenêutico de verificação do sentido que aparece nas práticas das pastoras que fundam igrejas. Estas chaves de sentido tem relação com outras práticas de mulheres na América Latina e com teorias descoloniais de autoras do continente sobre o fazer protagônico de mulheres e o enfrentamento da colonial modernidade. As seguintes chaves de sentido são identificadas na prática das pastoras:

* A 'fuga' das mulheres das igrejas patriarcais: a criação de pequenos refúgios - igrejas/comunidades de proteção;

* A criação ou recriação de pequenas comunidades: um projeto político e espiritual;

* A religião em chave doméstica: domesticar a religião, para uma religião 'domesticada';

* Desertar: a linguagem da rebelião. $O$ abandono da religião patriarcal colonial moderna - catolicismo, protestantismo clássico e pentecostalismo.

A pastora Francisca e a sua igreja

O sentido destas práticas das mulheres que fazem a sua própria igreja aparecem nas falas e, na casa, no culto, enfim, o sentido se mostra a partir de uma observação e participação sensível do contexto delas. A pastora Francisca diz, sentada em sua sala de culto e atendimento, quando me recebeu, a mim e Sandra - que me acompanhava,

Se não for por Deus ninguém faz nada, mas quem tem coração faz. Se a pessoa chama pelo nome de Jesus ele reprende o mal e a pessoa levanta. Pessoas com câncer, com caroços, com lepra - vai dos pés à cabeça. E as minhas testemunhas que falo são de pessoas vivas e não mortas. A moça ali do banco veio cheia de lepra. A pele dela tá limpinha. Eu curo para salvar almas para Jesus.

Eu não era daqui. Trabalhava na lavoura. Depois vim para cá e comprei esta casinha. Tem os documento aqui. Não foi dada, foi o moço que me vendeu. Ali eu moro, aqui é casa de Deus.

"Como a senhora começou aqui?" (pergunto). 
Eu era de uma igreja. Naquela igreja eu aprendi muita coisa. Tive dois anos na igreja (Universal), mas tinha um detalhe. Eu sempre procurava ficar na frente e as pessoas me levavam um bilhetinho e diziam: isso aqui é pra senhora fazer uma oração para a minha filha, o meu marido, sabe? Um dia o pastor me perguntou porque as pessoas me davam bilhetinho. Eu falei, pois é, porque não dão par ao senhor que é o pastor? E eu fazia oração na minha casa e as pessoas eram curadas de lá. É porque em mim já existia o poder de Deus.

Até o pastor depois chegou aqui e pediu oração. Eu também trabalho com ervinhas de chá. As mulher tem muito problema de útero e tal e ás vezes tem vergonha de ir no médico. É um dom de Deus.

Cobreiro de lesma, aquilo quanto mais remédio do médico você passa mais aquilo avança. Aqui vem pessoas de todas as posses. Eu abraço todas as pessoas, e eu amo essas pessoas. Pode trazer foto para abençoar. Veio um homem aqui, um fazendeiro que fazia três anos que se tratava em Porto Alegre. Encostou aqui com um carro bem fino. Ele veio aqui. Tinha uma coisa na cabeça que mexia. Falou que já gastou muito dinheiro. Fui lá na rua peguei um ramo e fiquei do lado direito dele, cortei aquele mal com a faquinha. A mulher dele voltou para agradecer, trouxe uma ajudinha para a casa. Falei obrigada Jesus..., porque a vida é tão difícil. E se tu vem aqui e traz um real e põe na mesa ali é uma ajuda. Mas se tu não traz nada tu recebe a bênção do mesmo jeito. A pessoa pode deixar o nome aqui no caderninho e eu faço oração. Eu também dou uma aguinha ungida para cada pessoa, aguinha da vida. A pessoa toma aquela água para ter vida. Eu sempre gostei de passar força para aquelas pessoas que não tem. Estão usando o nome de Deus para negócio. Isso está errado.

Eu nunca fui católica. Eu sempre fui evangélica. A fé da minha família é uma e a minha é outra. A pessoa traz um documento e eu toco no documento e faço oração. Só que tem um defeito, as pessoas vêm, melhoram de vida e depois viram as costas. Viram as costas não é para mim, mas é para Jesus. Um homem veio aqui e foi curado depois de 20 anos doente.

(Mostra a documentação. Tem alvará de licença).

Impressões, ritual e chaves de sentido

Saí de lá com a convicção de que eu estava diante de uma benzedeira/curandeira, que se apresentou como evangélica. Algo bastante raro, uma vez que no mundo evangélico benzedeiras não são bem vis- 
tas (elas ainda são mulheres que trabalham com coisas ocultas como as antigas bruxas). Ela afirmou claramente seu poder de oração e seu trabalho com "ervinhas". Como seria, então, um culto com uma senhora idosa benzedeira/curandeira? Pois diferente e além dos atendimentos individuais de uma benzedeira ela reúne pessoas para um culto. Algo inusitado. No dia seguinte voltei para participar do culto. Neste culto, a comunidade participante era composta de pessoas adultas e crianças, jovens, homens, mulheres e crianças. Pessoas idosas, classe social média e baixa, pessoas negras e brancas.

A pastora Francisca, esta senhora que aparentava ter entre 70-80 anos, de cabelos brancos e longos, estava acompanhada de duas pessoas, que junto com ela oficiavam o ritual. Uma mulher (Catarina), de mais ou menos 40 anos, que fazia um fundo de oração, louvor e clamor, e um homem (Joanildo), negro de pele muito escura. O homem, com a Bíblia na mão, do mesmo modo que a pastora Francisca e Catarina, entoava sons estranhos que aludiam a um transe durante os mesmos cantos do $C D$. Estas músicas tinham ritmos animados em estilo sertanejo religioso. Foram dezenas de músicas tocadas durante a hora e meia de reunião. Cada pessoa que ia chegando no culto estendia a mão e silenciosamente pedia bênção para cada uma das lideranças. Algumas pessoas cochichavam palavras no ouvido da pastora. Certamente algum pedido de oração, alguma queixa, alguma necessidade que havia. Bebês eram recebidos com sorrisos e afagos pela pastora.

A pastora Francisca estava, pois, acompanhada de duas pessoas, uma mulher e um homem, que mais que a pastora tinham um papel central. As três pessoas que lideravam aquele culto seguravam a Bíblia na mão, folheavam e refolheavam a Bíblia. Mas em nenhum momento leram algum trecho. Não houve leitura, não teve mensagem ou interpretação de algum texto sagrado no encontro. Não havia o apelo da palavra, a pregação. Não houve nenhuma palavra da pastora, a idosa, benzedeira, estava à frente da comunidade, sempre de pé, com a Bíblia aberta na mão. Uma senhora de idade chegou acompanhada de outra mais jovem. A senhora não estava passando bem e foi imediatamente "atendida" por Francisca, enquanto os cânticos seguiam. Francisca impôs as mãos sobre a cabeça da senhora e orou, depois ungiu com óleo 
seu rosto e esfregava seu peito com óleo. A senhora pareceu melhorar e se acalmar até o final do culto.

Até aqui, posso pensar que o sentido daquele encontro e culto era uma vivência comunitária de estar junto, pertencer, compartilhar a vida em uma pequena comunidade.

Na última meia hora do culto o ritual mudou. As três lideranças mudaram de tática e agora o auge do rito se baseia em símbolos, gestos, toques. Joanildo, Catarina e a pastora Francisca passaram pessoa por pessoa ali sentada abençoando, orando e ungindo com óleo cada uma. Suas orações eram pessoais, com as mãos postas sobre a cabeça de cada qual, suas unções com óleo eram na testa, no rosto, no peito, com palavras fortes e individuais. Todas as pessoas foram ungidas. $\mathrm{Na}$ sequência uma bandeja com pequenos copinhos foi passando para que cada pessoa tomasse a "água da vida", água ungida pela pastora.

Depois disso, o culto foi finalizando. As pessoas, já conhecedoras do encontro, foram se levantando, se despedindo das três lideranças e mais uma vez foram recebendo palavras de ânimo, consolo e força da pastora.

O culto da pastora Francisca colocou uma série de interrogações para o modelo de culto que eu esperava. De certo modo eu gostaria ou poderia dizer que o culto não era um culto, a pastora não era uma pastora, a casa não era uma igreja. Não havia leituras de textos sagrados, ainda que o texto sagrado estivesse nas mãos das lideranças e as músicas tivessem conteúdo religioso evangélico (a pastora foi evangélica desde a infância, como disse na entrevista). Nada próximo do padrão conhecido. Ou seja, a centralidade de um culto evangélico, tradicionalmente, está na ênfase da Palavra, do texto sagrado lido e interpretado. O papel central estaria reservado para a pastora que lideraria o culto colocando ênfase em um discurso oral, a pastora não seria tão idosa e "jamais" seria uma benzedeira. A casa seria uma igreja, pelo menos com uma placa com algum nome criado para denominar a igreja.

A casa de reunião espiritual criada por Francisca é de fato uma experiência que rompe em todos estes sentidos com o ritual religioso convencional de uma igreja evangélica. Francisca saiu de uma igreja evangélica pelo motivo de que era ela uma liderança, uma mulher com 
poder de oração e cura, que era assediada por pessoas que frequentavam sua antiga igreja e Ihe pediam oração dentro da igreja do pastor local. Diante da impossibilidade de exercer seu papel e seu poder naquela igreja, Francisca inicia sua própria "casa de oração", na sua casa, sob seu domínio e liderança. Ali ela cria algo a seu modo. É o seu modo de fazer religião. E seu modo inclui sua antiga sabedoria de benzer, orar, curar, e agora também de oferecer um ritual comunitário. Ela organiza um espaço doméstico, uma religião doméstica, onde supera a ordem da centralidade da palavra-feita-discurso-falado e enuncia um discurso em forma de canto, de toque, de unção, de água da vida/água abençoada, de imposição de mãos com palavras individuais. É uma comunidade de casa, de afeto, de atenção, de amor (como ela se expressou na entrevista: 'eu amo as pessoas que vem aqui. Eu as abraço e as amo'. $\mathrm{Na}$ comunidade a pastora atende individualmente em outros horários nos quais usa "ervinhas”, onde ela também 'abraça' e 'ama' as pessoas.

\section{A pastora Rosali e a sua igreja}

A pastora Rosali conta que cresceu na Igreja católica. Já casada, sofreu uma enfermidade do coração, quando foi internada em um hospital, aos 42 anos. Nesta ocasião, recebeu uma visita de um casal que Ihe falou de Jesus. Foi quando ela conheceu a Igreja Pentecostal Deus é a Salvação, aceitou Jesus e saiu da Igreja Católica. Passou por um divórcio. Naquela Igreja, diz,

[...] me interessei mais em conhecer e exercer a Palavra, me batizei e recebi uma revelação: o Senhor me dizia que precisava de mim. Mas como?, pensei, eu só tenho a quarta série! O Senhor estava querendo o meu serviço, mas um ministério sem placa. Aí entrou no meu coração um sentimento. Aí a igreja voltou para Sapucaia e eu entrei na Deus é Amor. Foi mais ou menos em 1995 e fiquei até 1998 fazendo serviço na Deus é Amor". Por este tempo "Deus falou com o pastor de lá que queria que eu dirigisse a igreja, como obreira auxiliar. Entrou em mim um temor pela reverência a Deus. O pastor me ungiu como dirigente pastora. Aí saí para evangelizar e onde eu ia juntava povos. Eu orava, instruía, educava os jovens, visitava os casais. Fiquei 17 anos, fundei cinco congregações na Igreja. Aí criaram uma perseguição porque queriam saber onde ia o dinheiro da congregação. Vieram em grupo, uma noite e me tiraram do meio do 
culto. Foi muito difícil, uma grande vergonha. Porque me tirar do meio do culto? Antes tentaram com o argumento financeiro, mas não deu certo porque eu tinha tudo anotado. Aí alegaram a idade, que eu era velha demais".

Há três anos saiu de lá. Logo depois, em 23.02.2014 recebeu uma revelação de madrugada. "Era um ministério! E disse para confiar no Senhor. Aí a Igreja Evangélica Jesus o Nosso Pastor me adotou, em fevereiro de 2014". Naquele mesmo ano teve um AVC. Se recuperou e fundou seu próprio ministério, onde atua junto com sua filha, que é auxiliar. Fazem seus cultos em três lugares, lutam muito para manter, pagar o aluguel e as despesas.

Ritual e chaves de sentido

A igreja da pastora Rosali tem vários pontos de encontro na cidade e fora da cidade. O local que foi visitado por mim, é uma pequena casa de madeira, alugada, em rua de chão batido, na periferia da cidade. O interior da igrejinha parece uma casa, a sala de uma casa. Cuidadosamente arrumadinha, com cortinas, flores e aconchego. O culto da pastora Rosali tem fortes marcas das suas igrejas anteriores. Um ritual com formalidades e liturgia, no entanto com falas espontâneas e palmas para Jesus a qualquer momento, geralmente sob a iniciativa da filha da pastora (Margarida). A pastora tem pouco estudo, mas aprendeu em sua trajetória nas outras igrejas a fazer uma boa hermenêutica bíblica. A interpretação que fez do texto sagrado em de bom nível teológico, e apesar de seu apelo litúrgico pentecostal, sua pregação não era moralista. Neste culto, diferente do culto da pastora Francisca, havia espaço para testemunhos. A pastora Rosali, uma senhora de mais de 60 anos, faxineira, criou seu próprio ministério após passar por vários constrangimentos como os que relatou na citação acima.

\section{CHAVES DE SENTIDO PARA UMA COMPREENSÃO AMPLA DO MODO DE FAZER RELIGIÃO DAS MULHERES}

A ruptura, a criação de pequenas comunidades, a religião doméstica

O primeiro ato que caracteriza o modo de fazer religião das mulheres é a ruptura com a religião colonial patriarcal moderna. Romper com 
o modelo religioso colonial moderno e patriarcal implica em romper com a lógica dos grandes templos, romper com as grandes estruturas organizadas de forma hierárquica e dominadora, com suas leis, dogmas e teologias dominadoras. Significa romper com o conforto e ao mesmo tempo, e não raro, como é no caso das mulheres pastoras, ser excluída deste conforto financeiro que garante uma renda ordinária pelo serviço prestado a uma estrutura eclesiástica grande. Este ato de ruptura já resulta de um processo de empoderamento, que leva a uma autonomia. É um processo de autodomínio e proteção da sabedoria e experiência pessoal. Elas finalmente se apoderam de sua própria experiência e trajetória. Se dão conta do poder pessoal, de sua capacidade de liderar, entendem agora que seus dons determinavam, em boa medida, o sucesso de suas igrejas anteriores. Neste sentido, protegem sua sabedoria e experiência pessoal, não mais a submetem a ordem colonial de seus pastores e igrejas. Desprendem-se destas estruturas, enfrentam muitas dificuldades, mas sentem autonomia para se desenvolver como mulheres, e liberdade para propor ao mundo outro modo de organizar a vida espiritual. Elas não mais oferecem sua habilidade, sua experiência e seu dom para o senhor Pastor, de quem serão serviçais. Os dons delas sempre renderam bons ganhos financeiros para as igrejas. Elas deixarão seus pastores órfãos de sua liderança afetuosa, atenciosa, com seu poder de cura, seu poder de oração e sua capacidade de reunir, organizar e liderar pessoas.

Elas criam pequenas comunidades. Elas constroem ou desenvolvem outro projeto de religião. Criam uma religião doméstica. A religião doméstica é uma religião de pequenas comunidades, e é uma criação das mulheres. Sem dúvida é o modo de fazer religião das mulheres. No mundo doméstico elas cuidam, tratam, organizam a vida de pessoas, a rotina, as finanças, inserem seu trabalho em casa ou fora de casa no meio das demais atividades, com autoridade criam filhas e filhos, com habilidade criam redes de relações e ainda mantém e organizam a vida espiritual da família. Na cozinha usam temperos, tratam com chás, misturam ingredientes ao seu dispor, criam e gerenciam a vida das famílias. Ora, assim mesmo fazem religião. De longo tempo a vida espiritual ou religiosa já está a cargo das mulheres nas famílias. Na sua nova religião 
elas também cuidam e tratam espiritualmente das pessoas com "ervinhas", como diz a pastora Francisca.

Agora, no início do século XXI “domesticam”/domesticizam a religião. Trazem a religião do mundo público para o âmbito doméstico e lá criam uma estrutura própria e uma teologia. Lá fazem sua própria teologia, simples, intimamente relacionada com o cotidiano. No caso das pastoras Francisca e Rosali, abrem mão dos pesados e complexos discursos teológicos das igrejas convencionais. Criam até igreja sem discurso oral (Francisca) falado, não há pregação da Palavra, uma alocução com interpretação de um texto sagrado como é no modo convencional nas igrejas protestantes. Há apenas uma prática de estar junto, oração, unção, cuidado, cura por meio de ervas e oração. O discurso racional, tão próprio da área patriarcal, do domínio e da dominação pela palavra - modo tão convencional das tradições monoteístas e patriarcais, perde espaço.

Ali as mulheres fazem religião a seu modo. Os homens por longo tempo, desde a colonização, e já antes nas religiões monoteístas, fizeram religiões de longos discursos (veja os profetas na tradição judaico cristã). Fizeram missas em latim, ainda que o povo sequer falasse latim, fizeram discursos, alocuções, homilias, com uso do poder da língua e seus rebuscados recursos - distantes da linguagem popular. Certamente, este modo foi pouco efetivo no sentido de ensinar os verdadeiros fundamentos das grandes religiões. Discurso e prática religiosa eram e são questões muito distintas no sistema patriarcal.

Sabiamente as mulheres aproveitam as fissuras, as brechas do sistema religioso colonial e criam sua própria estrutura religiosa, seu modelo de culto. A pastora Francisca reúne seus conhecimentos de benzedeira/curandeira, reúne símbolos como a água e a abençoa para que se torne água da vida, água que cura, toma o símbolo do óleo e o usa para unção, prepara remédios e os recomenda, afasta o mal com orações. Depois reúne a comunidade para cantar, estar junto, criar vínculo. Cria uma pequena comunidade, não deixa as pessoas viver no isolamento, no individualismo.

Nas pequenas comunidades elas não lideram sozinhas. Fazem-se acompanhadas de mais pessoas. Desfaz-se a estrutura complexa e hierárquica das grandes igrejas. Seu poder é partilhado, horizontal. A centralidade do seu culto não está no discurso oral, na palavra falada. 


\title{
FUGA E REFÚGIO: A 'FUGA' DE MULHERES DAS IGREJAS DE TRADI-
} ÇÃO COLONIAL PATRIARCAL E A CRIAÇÃO DE PEQUENOS REFÚGIOS - IGREJAS/COMUNIDADES DE PROTEÇÃO

O refúgio e a fuga em busca de liberdade/libertação da opressão, da perseguição sofrida nas igrejas do padrão colonial moderno e patriarcal do qual as pastoras 'fogem', do qual buscam se libertar, criando - em suas casas, ou em pequenas casas, - pequenas igrejas, espaços seguros para suas práticas religiosas e espirituais é uma das imagens que podemos ter como um sentido para este movimento protagônico delas.

Com a colonização a caça às bruxas atravessou o oceano e chegou em Abya Yala, e aqui, chegou com o argumento ideológico de eliminar a idolatria. Ora, as protagonistas das supostas idolatrias eram as mulheres que conduziam os rituais ancestrais.

\begin{abstract}
"As mulheres, chamados sacerdotisas da história do mundo, yatiris ou sabedoras para nós, foram as que reafirmaram práticas ancestrais como uma forma de resistência, graças à Pachamama, para alimentar o wacas, práticas realizadas em lugares quase inacessíveis perto as montanhas ou apachetas. Estas 'atividades subversivas idólatras' (Silverblatt, 1990: 149) fizeram com que mulheres como Catalina Guacayllano ou Francisca Guacaquillay fossem perseguidos pelos extirpadores de idolatria, sendo o exílio a punição nas usinas, que eram centros de produção de tecidos, têxteis e outros produtos. Em uma tentativa desesperada para manter a cultura as ligava com outra forma de vida, nossas avós se refugiaram nas alturas formando comunidades autónomas de mulheres, ou como relatam os cronistas, sociedades somente de mulheres que resistiam à colônia, pastavam seus rebanhos e se defendam diante das autoridades, alguns cronistas mencionam suicídios de mulheres indígenas como uma forma de resistência e infanticídios, matavam seus filhos homens, provavelmente, para não crescerem nesse mundo ou para que não fossem enviados para trabalhar nas minas de onde não retornariam" (Julieta PAREDES; Adriana GUZMÁN, 2014, p. 24, tradução livre) ${ }^{12}$.
\end{abstract}

12 “Las mujeres, llamadas sacerdotisas por la historia universal, yatiris o sabedoras para nosotras, eran quienes reafirmaban las prácticas ancestrales como forma de resistencia, el agradecimiento a la Pachamama, dar de comer a las wacas, prácticas que realizaban en lugares casi inaccesibles, cerca de las montañas o apachetas. Estas 'actividades idolátricas subversivas' (Silverblatt, 1990: 149) hicieron que mujeres como Catalina Guacayllano o Francisca Guacaquillay fueran persegui- 
A imagem do refúgio para preservar suas práticas e seus saberes não está, pois, distante do que vemos fazerem hoje as mulheres em suas pequenas igrejas, como dito acima. Por um lado, está claro que as mulheres precisam se refugiar em suas casas -igrejas 'sem placas', se esconder, para criar seu próprio mundo espiritual/religioso e evitar perseguição. As mulheres e sua religião funcionam nas margens, aparecem nas fissuras do sistema religioso colonial, cujo poder é de ordem patriarcal e monoteísta até os dias atuais. Elas foram perseguidas em diferentes tempos já antes do cristianismo. Há relatos nos textos da história do povo hebreu, na Bíblia, no Primeiro Testamento (na Bíblia, no livro de Gênesis, capítulo 31) que dão conta que Raquel leva consigo, "rouba" e esconde as divindades domésticas ao deixar a casa de seu pai. A dita "idolatria" das mulheres e também do povo é conhecida em diferentes textos do mundo judaico cristão. Por outro, elas e sua forma de fazer religião denuncia a violência e a imposição do deus único, do modelo sagrado do monoteísmo, que nem sempre parece atender as necessidades das mulheres e do povo.

As rupturas, as desobediências, o silenciamento, as "fugas" - reais ou simbólicas - para as montanhas ou para suas casas para fundar pequenas igrejas, o abandono de toda forma de religiáo como é o caso das mulheres e sua comunidade de Noiva do Cordeiro no interior de Minas Gerais (Anete ROESE, 2015) a violência contra as mulheres e sua religião como aconteceu na inquisição, em outros momentos da história e ainda hoje dão conta da implacável guerra de com aparato colonizador, de perseguição, isolamento, ameaça e morte, contra o poder religioso e espiritual das mulheres. Contra Jacobina Maurer a Igreja Evangélica de Confissão Luterana, aliada ao governo da época, no século XIX'13, em-

das por los extirpadores de idolatrías, siendo el castigo el exilio en los obrajes, que eran centros de producción de telas, tejidos y otros productos. En un intento desesperado por mantener la cultura que las ligaba con otra forma de vida, nuestras abuelas se refugiaron en las alturas conformando comunidades autónomas de mujeres, o como relatan los cronistas, sociedades sólo de mujeres que resistían a la colonia, pastaban sus rebaños y se defendían entre sí ante las autoridades, algunos cronistas mencionan suicidios de mujeres indígenas, como forma de resistencia e infanticidios, mataban a sus hijos varones probablemente para que no crecieran en ese mundo o para que no fueran enviados al trabajo en las minas de donde no volverían".

13 Veja referências SCHULTZ, Adilson.

Mandrágora, v.24. n. 2, 2018, p. 161-200 
preendeu uma guerra real, sangrenta, matando Jacobina, familiares e seguidoras e seguidores.

O monoteísmo é binarista em sua cultura é formatado para o gênero masculino preferencialmente. No entanto, mesmo nos pequenos redutos religiosos onde as mulheres aparecem como lideranças em rituais, com acesso ao sacerdócio a vigilância sobre elas é constante, é rigorosa como ave de rapina. Seu protagonismo um pouco acentuado será duramente, mas sutilmente, repreendido como se elas estivessem agindo fora do padrão. Elas só poderão ocupar os melhores espaços sob muito custo.

Em sistemas religiosos pré-intrusão e não monoteístas de que temos notícia as mulheres têm ou tiveram mais autonomia e protagonismo no domínio do espaço sagrado, na manipulação dos símbolos e condução dos rituais. Assim é nos espaços sagrados das tradições afro no Brasil e parece ter sido assim antes da dominação colonial moderna em Abya Yala. A clandestinidade a que foram relegadas as mulheres no âmbito religioso pertence ao pacto da desigualdade firmado no seio do entronque patriarcal, como dizem Julieta Paredes e Adriana Guzmán desde o feminismocomunitário.

Por outro lado, o sistema delas também é um modo de resistência delas. Estas resistências são poucos historicizadas. Falta descolonizar a memória das lutas das mulheres - dizem no feminismocomunitário Julieta Paredes e Adriana Guzmán. "As lutas e resistências de nossas avós eram anti-sistêmicas, anti-coloniais, feitas a partir de seus conhecimentos e da comunidade, não do individualismo liberal burguês" (Julieta PAREDES; Adriana GUZMÁN, 2014, p. 25, tradução livre) ${ }^{14}$.

\section{A CRIAÇÃO OU RECRIAÇÃO DE PEQUENAS COMUNIDADES: UM PROJETO POLÍTICO E ESPIRITUAL}

Julieta Paredes e Adriana Guzmán, do feminismocomunitário ${ }^{15}$ da Bolívia ajudam a pensar um sentido/um significado possível para o fenô-

14 Las luchas y resistencias de nuestras abuelas fueron antisistémicas, anticoloniales, hechas desde sus saberes y desde la comunidad, no desde el individualismo burgués liberal.

15 Esta é a forma usada para escrever - feminismocomunitário. Uma só palavra. Assim sustentam Julieta Paredes e Adriana Guzmán. 
meno das pequenas igrejas e comunidades inventadas pelas pastoras. As pastoras não são feministas, não tem um movimento organizado. Elas são mulheres, na maioria pobres, de baixa escolaridade. Isso não significa que não possam tomar iniciativas de protagonismo, de autonomia, tomar decisões que mudam o rumo da sua vida e que instaurem processos de mudança social.

O 'feminismocomunitário' sustenta que o feminismo constitui uma teoria suficientemente completa para explicar as opressões. Não raro o 'feminismo ocidental' se mostra como uma teoria que precisa completar outras teorias ou que precisa se completar com outras fontes. Segundo Julieta Paredes e Adriana Guzmán estes caminhos impedem a autoafirmação do feminismo como projeto político e teoria, dificulta a autonomia das mulheres e das feministas em seu processo de libertação. Para as autoras, a redução do feminismo à luta contra as opressões que mulheres sofrem por parte dos homens seria limitar o feminismo para a finalidade de revisão das relações de gênero e igualmente seria limitar patriarcado a gênero. Isso resultaria em reconhecer que as mulheres sofrem apenas opressão de gênero, ignorando as opressões de raça, classe, sexo e demais (Julieta PAREDES; Adriana GUZMÁN, 2014, p. 36).

O feminismocomunitário ${ }^{16}$ desde a América Latina propõe outra visão, menos reducionista, pois há outros corpos em jogo, outras peles, outras memórias. São corpos de outros continentes, de outros solos, outros climas, de outra experiência moral, religiosa... Como ato descolonizador propõe uma revisão do feminismo e do patriarcado, apresentando um feminismo que não necessite de adjetivações (feminismo socialista, marxista, liberal...) e complementações, que é uma teoria em si, que explica as opressões da humanidade e da natureza e, ademais, apresenta uma proposta. O ponto de partida no feminismocomunitário é justamente a ‘comunidade'. A Comunidade como ‘forma de vida' e como 'projeto político'. "Comunidade como projeto político, como horizonte de possibilidades, como utopia que se constrói e por isso sua enunciação é desde a proposta feminismocomunitário também uma só, porque a comunidade não é uma teoria ou uma ideologia, a

16 O feminismocomunitário é uma corrente política e uma teoria social latino-americana criada na Bolívia em 2006 pelas Mujeres Creando Comunidad e pela Assembleia Feminista de La Paz. 
comunidade simplesmente ou complexamente é"17 (Julieta PAREDES; Adriana GUZMÁN, 2014, p. 36, tradução livre). A criação de comunidades é no caso das pastoras uma intuição e projeto espiritual, um projeto que constitui seu modo de fazer religião inserida na vida.

O aporte do feminismocomunitário leva a outra episteme que não a eurocêntrica. Esta outra mirada epistêmica implicará em revisões e outras definições de feminismo e patriarcado. Outros princípios, outros pontos de partida, outras lógicas. A começar pela referência à comunidade e não ao indivíduo, sujeito, ainda que este seja uma mulher. São as mulheres e suas comunidades o ponto de partida. São comunidades específicas, locais, continentes e não as mulheres europeias e suas trajetórias a referência. Ou seja, está colocado o enfrentamento a ideia universal de mulher e, ademais, a mulher europeia, sua história, sua trajetória como referência para todas as mulheres. É necessário, inclusive, descolonizar a temporalidade, o que significa recorrer à referência de tempo que não a colonial - linear, referida como única, que ideologicamente propõe uma ideia de progresso, de superação de um passado retrógrado e um futuro que supera o passado e melhor que o presente, uma evolução referida como moderna, civilizada e uma noção de pré-moderna como primitiva, não civilizada. Julieta Paredes e Adriana Guzmán (2014) contam que para seus povos, quechua e aymara, é preciso caminhar olhando para o passado porque o passado está à frente, se pode vê-lo, enquanto o futuro está atrás, não pode ser visto. Outro eixo de embate com a episteme eurocêntrica é que as feministas do feminismocomunitário não se proclamam filhas do iluminismo e não reclamam os mesmos direitos que o feminismo iluminista moderno, cujas lutas eram as da classe burguesa, com seu pensamento individualista. As bandeiras da igualdade entre os sexos, cidadania, direitos, propriedade privada, e ainda a razão e a humanidade sobreposta à natureza, base da luta e das heranças do feminismo liberal, não são as mesmas das mulheres em suas comunidades no contexto do feminismocomunitário.

17 la comunidad, como proyecto político, como horizonte de posibilidades, como utopía que se construye y por eso su enunciación es desde la propuesta, feminismocomunitario, también una sola I porque la comunidad no es una teoría o una ideología, la comunidad simple o complejamente, es. 
No processo das minhas leituras para encontrar um sentido de compreensão para o que as mulheres-pastoras estão fazendo ao redor das grandes cidades do Brasil, e nos bairros, centros e periferias das pequenas cidades, sigo lendo a obra de Julieta Paredes e Adriana Guzmán (2014) intitulada 'El tejido de la rebeldia. Qué es el feminismocomunitário?’. Me indago sobre o que significam as iniciativas das pastoras, o que o movimento delas, seu modo de fazer religião diz, o que aportam desde sua ruptura com uma religiosidade colonial moderna. É claro que elas não se dizem feministas. Como também não se dizem feministas as mulheres indígenas da zona rural da Bolívia, de onde escrevem Julieta Paredes e Adriana Guzmán sobre e desde feminismocomunitário. Tampouco quero o título de feministascomunitárias para elas. Mas o feminismocomunitário de Julieta Paredes e Adriana Guzmán me ajuda a pensar algo que considero um sentido central do que fazem as pastoras, que é justamente a sua intuição e intenção de criar comunidade e de pensar a vida não sem formar comunidade.

"O Feminismocomunitário é o WARMIKUTI, ou seja, o regresso, o retorno das mulheres na comunidade, feito histórico e imprescindível para o PACHAKUTI." ${ }^{18}$ E "não haverá Pachakuti, que é o regresso do espaço, o tempo e o movimento de nossos povos originários, não haverá Pachakuti se não há o retorno das mulheres na comunidade para o equilíbrio da comunidade" 19 (Julieta PAREDES; Adriana GUZMÁN, 2014, p. 60, tradução livre).

Este feminismo se diferencia do feminismo de Estado, do feminismo das ONGs e do feminismo acadêmico, segundo as autoras. Estes, "sem reconhecê-lo, eles se tornam feminismos sistêmicos que pagam o

18 El Feminismocomunitario, es el WARMIKUTI, o sea el regreso, el retorno de las mujeres en la comunidad, hecho histórico e imprescindible piara el PACHAKUTI. (... e não haverá) Pachakuti que es el regreso del espacio, el tiempo y el .oO movimiento de nuestros pueblos originarios, no habrá Pachakuti, sino hay el retorno de las mujeres en la comunidad, para el equilibrio de la comunidad.

19 No habrá Pachakuti, que es el regreso del espacio, el tiempo y el movimiento de nuestros pueblos originarios, no habrá Pachakuti, sino hay el retorno de las mujeres en la comunidad, para el equilibrio de la comunidad. 
patriarcado com seu colonialismo, heterocentrismo e despolitização" 20 (Julieta PAREDES; Adriana GUZMÁN, 2014, p. 57, tradução livre). Feminismos sem movimento e sem proposta. $O$ "tecer nossas rebeldias para que sejam revoluções cria um movimento que se faz permanentemente, que tece figuras e cria símbolos, onde os fios diferentes se cruzam, o movimento é movimento que não se paralisa, não se estabiliza, não para, não vira norma, não se institucionaliza, não dá lugar ao caudilhismo, à corrupção, nem às reformas, porque não é desde o individualismo que se tece, mas desde todas e todos em comunidade" ${ }^{21}$ (Julieta PAREDES; Adriana GUZMÁN, 2014, p. 57, tradução livre). Ademais, dizem, o movimento é uma metodologia que, desde um pensamento comunitário, permite articulações com outros grupos e instâncias, dado que a libertação também não pode ser pensada de forma individualista, porque deve se dar em comunidade, pois cada qual é responsável pela própria libertação, mas também é responsável pela libertação de outras pessoas.

O feminismocomunitário é isso, é o movimento social das mulheres, para recuperar o equilíbrio, é recuperar a pacha (espaço, tempo e movimento) das avós, recuperando assim, também as nossas, filhas e netas dos povos andinos, nas aldeias, o nosso tempo nas cidades, nos ayllus e nas comunidades (Julieta PAREDES; Adriana GUZMÁN, 2014, p. 60, tradução livre $)^{22}$.

Suspeito que a intuição profunda das mulheres-pastoras que formam pequenas igrejas-comunidades, comunidades-nem-sempre-igrejas, tem a ver com a noção de retorno das mulheres, como um movimento social não organizado, mas intuído, um retorno para a comunidade,

20 sin reconocerlo se constituyen en feminismos sistémicos que tributan al patriarcado con su colonialismo, heterocentrismo y su despolitización.

21 El tejer nuestras rebeldías para que sean revoluciones crea un movimiento que se hace permanentemente, que teje figuras y crea símbolos: donde los hilos diferentes se cruzan, el movimiento es movimiento no se paraliza, no se estatiza, no se para, no se vuelve norma, no se institucionaliza, no da paso a los caudillismo, a la corrupción ni a las reformas, porque no es desde el individualismo que se teje, sino desde todas y todos en comunidad.

22 El feminismocomunitario es eso, es el movimiento social de las mujeres, para recuperar el equilibrio, es recuperar el pacha (espacio, tiempo y movimiento) de las abuelas, recuperando de esa manera, también el nuestro, hijas y nietas de los pueblos andinos, en los pueblos, nuestro tiempo en las ciudades, en los ayllus y comunidades. 
para o equilíbrio da comunidade. É o retorno delas para recuperar o equilíbrio, recuperar o pacha - o espaço, o tempo, o movimento. Com isso não estou pensando em aplicar categorias para dar andamento a uma explicação de um evento simplesmente. Penso mesmo na intuição profunda que as mulheres-pastoras tem do seu papel e seu lugar no mundo neste momento histórico, onde a Religião e o Estado colonial modernos perseguem mulheres e as deixam no limbo do sistema. Mesmo ali elas produzem uma ruptura e criam um movimento de pequenas comunidades. O que define o feminismocomunitário é a proposta de comunidade, e esta define a proposta de sociedade. Uma sociedade é uma "Comunidade de comunidades" ${ }^{23}$ (Julieta PAREDES; Adriana GUZMÁN, 2014, p. 60).

Observando o modo de fazer religião das pastoras veremos que o princípio fundamental que orienta seu modo de estar no mundo é a formação e a vida de comunidade. Mesmo aquela que atende pessoas individualmente para fazer orações e curas, cria um espaço de encontro, espaço comum de convívio, com oração, bênção, canto, com símbolos e rituais. As igrejas das pastoras são criações delas diante de perseguições, autoritarismos, exclusões e falta de reconhecimento de sua liderança e autoridade nas igrejas anteriores. No seu modo de fazer religião aparece uma comunidade espiritual, gerenciada com o apelo doméstico inclusivo, circular, que distribui a palavra, o gesto, o símbolo como quem põe a comida na mesa para que todas as pessoas da casa se sirvam.

O feminismocomunitário é um convite para mudar o mundo, mudar desde práticas sociais não hierárquicas. Julieta Paredes e Adriana Guzmán afirmam que neste contexto do feminismocomunitário as mulheres mais pautam uma prática descolonial do que uma teoria. Ou seja, se trata mais de fazer descolonização do que afirmar, se trata de exercitar a autonomia epistêmica, que implica na construção de um conhecimento descolonizado. Um conhecimento útil, que nasce de práticas sociais, que performam uma proposta teórico política.

O feminismo comunitário recupera a energia espiritual de nossos corpos, nossos sonhos e nossas lutas. Esta recuperação significa

23 Comunidad de Comunidades. 
denunciar a manipulação e usufruto, de fazem uso as instituições patriarcais, especialmente as Igrejas, manipulando os legítimos desejos de sentir, convocar e trabalhar as energias que emanam de nossos corpos, manipulando amor, prazer, desejo, as esperanças e utopias, estas energias as transformam em religiões, em Igrejas opressivas de mulheres e de homens não machistas (Julieta PAREDES; Adriana GUZMÁN, 2014, p. 62, tradução livre) ${ }^{24}$.

Rita Segato, como antropóloga e conhecedora do feminismocomunitário, lembra que uma comunidade precisa, para ser comunidade, de densidade simbólica e autopercepção dos membros de que compartiIha uma história comum (Rita SEGATO, 2016). E fala da importância de 'retecer' comunidade neste momento da história e da importância dos projetos disfuncionais ao capital. Fazer ou retecer comunidade implica em compartilhar um projeto distinto daquele do capital ou funcional ao capital. Para Rita Segato, a religião (cosmos próprio) tem um papel importante. A autora diferencia e tipifica projetos funcionais e disfuncionais ao capital. Entre estes também as religiões e suas vertentes - funcionais ou não ao capital - incompatíveis entre si. A tipificação do funcional e disfuncional ao capital é relativa aos projetos históricos distintos de cada agência empenhada em um projeto. Há "o projeto histórico das coisas e o projeto histórico dos vínculos" Como dito, são "dirigidos a metas de satisfação distintas, em tensão e em última instância incompatíveis"25 (Rita SEGATO, 2016, p. 29, tradução livre).

Neste caso, as igrejas das pastoras são projetos disfuncionais ao capital, não coadunam com o projeto do capital. Enquanto boa parte das igrejas, movimentos religiosos e religiões são hoje projetos funcionais ao capital, ou seja, coadunam com o projeto colonial, moderno e capitalista, e colaboram com o projeto patriarcal - que integra a colonial moder-

24 El Feminismocomunitario recupera la energía espiritual de nuestros cuerpos, nuestros sueños y nuestras luchas. Esta recuperación significa denunciar la manipulación y usufructo, que de esa fuerza hacen las instituciones del patriarcado, especialmente las Iglesias, manipulando los legítimos deseos de sentir, convocar y trabajar las energías que emanan de nuestros cuerpos, manoseando el amor, el placer, el deseo, las esperanzas y las utopías, estas energías las convierten en religiones, en Iglesias opresoras de las mujeres y de los hombres no machistas.

25 el proyecto histórico de las cosas y el proyecto histórico de los vínculos (Como dito, são) dirigidos a metas de satisfacción distintas, en tensión y en última instancia incompatibles. 
nidade e a lógica do capital. Segundo Rita Segato, "certos 'cosmos' e espiritualidades, muito distantes de ser 'o ópio dos povos', constituem, certamente, valas disfuncionais ao capital”26 (Rita SEGATO, 2016, p. 29, tradução livre). Ter como projeto político a vida em comunidade, como no feminismocomunitário, as Noivas do Cordeiro, as pastoras que fundam suas igrejas, é certamente uma vala disfuncional ao capital.

\section{A RELIGIÃO EM CHAVE DOMÉSTICA: DOMESTICAR A RELIGIÃO, PARA UMA RELIGIÃO 'DOMESTICADA' - O MODO DE FAZER RELI- GIÃO DAS MULHERES}

Rita Segato propõe uma inversão da formulação feminista dos anos 70 que afirmava o privado como político. Rita descarta a ideia de forçar a politicidade do doméstico por meio da tradução do mesmo para termos públicos para que obtenha reconhecimento. Um outro caminho é "domesticar a política" o que significa "humaniza-la em chave doméstica", significa tomar o caminho de uma "domesticidade repolitizada" e de uma desburocratização da política" ${ }^{27}$ (Rita SEGATO, 2016, p. 25, tradução livre). Temos visto que o Estado tomado por força ou por eleições é um fracasso, sobretudo porque o Estado se torna "sede de uma elite administradora" e colonial no caso da América Latina. A vida das comunidades, a vida comum desenvolveu e vive de experiências plurais e politicidades que podem ser reconhecidas e reaproveitadas, diz Rita Segato (2016).

O enfrentamento do binarismo público-privado, que tão bem funciona para a matriz colonial moderna, deve nos levar à restauração das "tecnologias de sociabilidade e uma politicidade que resgate a chave perdida da política doméstica, das oiconomias... assim como os estilos de negociação, representação e gestão desenvolvidos e acumulados como experiência das mulheres ao longo de sua história em sua condição de grupo diferenciado da espécie, a partir da divisão social do trabalho"28 (Rita SEGATO, 2016, p. 25, tradução livre).

26 ciertos «cosmos» y espiritualidades, muy lejos de ser «el opio de los pueblos», constituyen, ciertamente, vallas disfuncionales al capital.

27 domesticar la política, humanizarla en clave doméstica, domesticidad repolitizada, desburocratizarla.

28 las tecnologías de sociabilidad y una politicidad que rescate la clave perdida de la política doméstica, de las oiconomías (Segato 2007b), así como los estilos de negociación, representación y gestión desarrollados y acumulados como experiencia de las mujeres a lo largo de su historia, en su condición de grupo diferenciado de la especie, a partir de la división social del trabajo. 
O enfrentamento do binarismo no âmbito religioso, implantado deste a empreitada colonizadora no Brasil, e atualizado na modernidade, implica no reconhecimento de novas teologias, novas liturgias, novas atrizes no espaço do sagrado. Significa dar o tempo necessário para o processo de amadurecimento das novas tecnologias e agências no modo de ser religião a partir do mundo das mulheres e suas casas. As pesquisas sobre as casas das mulheres e suas igrejas tem a função de etnografar os movimentos e mostrar o que se dá de modo que possamos saber de forma mais explícita o que existe.

Para as pastoras é oferecida a chance de permanecerem em "igrejas de verdade", onde podem exercer sua liderança subserviente. Ao não se adaptarem são expulsas ou devem sair. Ao saírem sairão da margem condicionada do reconhecimento. Ficarão à margem das pesquisas de grande porte e do cunho acadêmico patriarcal dominante que considerará as grandes tradições e aquelas de público considerável, ou as de grande mídia; ficarão à margem teológica - pois sua teologia não terá relevância acadêmica. A Reforma destas mulheres passou ao largo dos festejos de 500 anos de Reforma Protestante comemorada em 2017.

Uma das estratégias do patriarcalismo religioso é o discurso - sua força, o poder da palavra, do gesto, do ato, substrato da estrutura, aliado ao peso da história discursiva. Sabemos o que nos dizem os dados do senso religioso e da vida prática dos fiéis das igrejas que sustentam o cristianismo - que indicam para uma severa crise com a drástica diminuição de participação de fiéis. No entanto, a negação dos dados, o silêncio sobre os mesmo é uma política de manutenção de um padrão religioso de dominação branca e práticas masculinistas.

Rita Segato chama a atenção para o "totalitarismo da esfera pública", a "fé estatal" e sua crise no atual momento. A fé cega no Estado tem como base o "autoritarismo da utopia". Concepções teológicas caras ao cristianismo como a esperança de um Reino (futuro) de Deus onde 'voltaremos' ao paraíso aparecem como utopia autoritária. Há que acompanhar um raciocínio fundamental para enfrentar o dilema que aqui se impõe (Rita SEGATO, 2016, p. 26).

A ideia de uma "sociedade futura perfeita para a qual uma eficaz apropriação do Estado e um controle administrativo nos conduziria 
triunfalmente nunca deixaram de ser autoritárias"29 (Rita SEGATO, 2016, p. 26, tradução livre). Rita Segato associa a abstração utópica a um evolucionismo eurocêntrico, onde mesmo o irreal e incerto pode ser controlado. A saída que escapa, visualizada pela autora, que foge da "neurose de controle" - marca da civilização europeia, é voltar o nosso olhar para as "experiências concretas que os povos de organização comunitária e coletiva põe em prática ainda hoje e entre nós para limitar a acumulação descontrolada e coibir a brecha de desigualdade entre os seus membros"30 (Rita SEGATO, 2016, p. 26, tradução livre).

A promessa de um Reino futuro de Deus deixou de convencer as mulheres trabalhadoras rurais de baixa escolaridade da Comunidade Noiva do Cordeiro. Depois de décadas de excomunhão da igreja católica e décadas de fundamentalismo religioso sob uma igreja evangélica elas começaram a questionar a ideia de que só aquela comunidade iria para o céu. Ora, "o céu é tão grande, o mundo tem tanta gente e só nós ir pro céu?... e assim foi, e largamos a religião." ${ }_{31}$

Discursos religiosos pouco factíveis são fatais. Essas mulheres optaram pela prática de uma vida comunitária que lembra as comunidades cristãs primitivas - dividiram bens e abdicaram do discurso futurista do Reino de Deus. As pastoras que fundaram suas próprias igrejas ignoram o discurso blefe da interpretação fundamentalista da Bíblia cujo argumento pauta a continuidade da dominação masculina do espaço sagrado e respondem com o argumento teológico do "chamado de Deus" para que elas assumam o sacerdócio.

Rita Segato (2016) se refere a uma politicidade em chave feminina que ainda pode ser recuperada, uma vez que foi perdida, censurada, junto com a história das mulheres na passagem do mundo-aldeia para a modernidade colonial. Rita Segato nos fala do resgate de uma política em chave feminina e, a leitura dos seus textos no momento da pesquisa em questão aqui me leva a propor a ideia da religião em chave "femini-

29 sociedad futura perfecta, a la que una eficaz apropiación del Estado y control administrativo deberían conducirnos triunfalmente, nunca han dejado de tornarse autoritarias.

30 las experiencias concretas que los pueblos de organización comunitaria y colectiva todavía hoy, y entre nosotros, ponen en práctica para limitar la acumulación descon- trolada y cohibir la grieta de desigualdad entre sus miembros.

31 Veja o Documentário Noivas do Cordeiro, GVT, 2008, disponível na internet. 
na" - no sentido do modo de fazer religião das mulheres que fundam suas igrejas. Este outro modo de fazer política, diz ela, surge na "razão doméstica, com suas tecnologias próprias de sociabilidade e de gestão" que não compartilha da burocracia e do racionalismo moderno como acontece com a política da colonial-modernidade. A história não é um projeto a ser realizado pelo Estado (Rita SEGATO, 2016, p. 29). Ora, esta 'razão doméstica, com suas tecnologias próprias' é também justamente a questão central do modo de fazer religião das mulheres. Caminhos alternativos aos sequestrados pela colonial-modernidade significam, para Rita Segato, voltar-se para a experiência comunitária e a partir dela tecer (retecer) comunidade desde os "fragmentos existentes" (Rita SEGATO, 2016, p. 27). Este ato implica, então, em também restaurar uma 'politicidade' ocultada, esquecida, dominada pela política pública. Ou seja, este caminho de 'restaurar uma religiosidade ocultada e dominada' pelas grandes religiões monoteístas é um movimento, é uma cena, é um ato presente nas centenas de pequenas iniciativas religiosas sendo criadas Brasil afora. Este outro modo de fazer religião surge na "razão doméstica, com suas tecnologias próprias de sociabilidade e de gestão" que não compartilha da burocracia e do racionalismo moderno como acontece com a religião da colonial-modernidade.

Rita Segato diz sobre uma "outra maneira de fazer política". Esta ideia nos dá a chave para pensar a outra maneira de fazer religião. Esta religião feita no âmbito doméstico, que exercita uma fé pautada em "vínculos, uma gestão vincular, de aproximação e não de distâncias protocolares e de abstração burocrática"32 (Rita SEGATO, 2016, p. 27, tradução livre). Esta forma de fazer religião no âmbito doméstico pelas mulheres pode fazer frente ao modelo de religião colonial da modernidade.

Está em jogo pensar a 'religiosidade do doméstico', uma reumanização da religião em chave doméstica. A religião em chave doméstica, uma religião doméstica, domesticada, uma retomada do caminho religioso em sentido espiritual. É outra maneira de fazer igreja/religião - esta religião que se faz no âmbito doméstico, como as pastoras voltam a fazer. Lembrando que as mulheres negras/o povo negro nunca deixou

32 vínculos, una gestión vincular, de cercanías, y no de distancias protocolares y de abstracción burocrática. 
de fazer sua religião no âmbito doméstico] nas tradições de matriz africana no Brasil. Certamente esta memória e a mobilidade religiosa das mulheres pastoras traz deste contexto das tradições afro o modo de fazer religião no mundo doméstico.

\section{DESERTAR: A LINGUAGEM DA REBELIÃO. O ABANDONO DA RELI- GIÃO PATRIARCAL COLONIAL MODERNA - CATOLICISMO, PROTES- TANTISMO CLÁSSICO E PENTECOSTALISMO}

Rita Segato, no capítulo Cambio religioso y des-etnificación: la expansión evangélica en los Andes Centrales de Argentina, de seu livro La Nación y sus Otros (2007), investiga a conversão religiosa ao protestantismo nos Andes Argentinos de populações que anteriormente pertenciam às antigas tradições do catolicismo popular dos Andes. A autora pergunta sobre as mudanças culturais que acompanham esta conversão - se seriam profundas; pergunta pelo repertório religioso simbólico novo a ser incorporado - seu conteúdo e adaptações; pergunta sobre a aceitação de um outro conteúdo religioso e como se dá, quais seriam os indicativos para esta alternativa; e pergunta se este fato a conversão implica em uma mudança efetiva ou em que medida é apenas uma continuidade (Rita SEGATO, 2007, p. 28).

As famílias tradicionais - com rede de influência e parentesco, com representantes em partidos políticos e poder econômico residem no local há mais tempo e se apropriaram das festas populares - carnaval, páscoa em Quebrada, Tilcara e Humahuaca. No entanto, já há grupos desertores - que não se sentem incluídos, representados e buscam "um espaço próprio onde possam se agregar e inscrever sua existência como um grupo distinto em um plano simbólico de existência" 33 (Rita SEGATO, 2007, p. 218, tradução livre). São grupos formados por pessoas que vieram de outros lugares e a escolha entre Protestantismo e a continuidade do catolicismo implica em um confronto entre o já estabelecido e o 'novo'- no caso de Quebrada.

A ideia de que as pastoras com as pessoas que são suas seguidoras são desertoras parece é plausível. Elas e seus grupos são a parte da

33 un espacio propio capaz de agregarlos e inscribir su existencia como un grupo distinto en un plan simbólico de existencia. 
sociedade abominada, que não se sente incluída e também busca um espaço e uma forma para celebrar sua fé com autonomia, para congregar e, como disse Segato, um lugar onde possam "inscrever sua existência como um grupo distinto em um plano simbólico de existência". Nos grandes templos do monoteísmo colonial as diferenças de classe são negadas ou suavizadas como se fossem inexistentes e a moral de gênero, de classe, de raça que impera é a moral teológica colonial.

Nesta pesquisa nos Andes Argentinos, em Quebrada, Tilcara e Humahuaca, Rita Segato nos fala das mudanças religiosas como uma linguagem de rebelião e se pergunta o que dizer sobre a "ruptura" com o catolicismo/a religião do Estado na ótica dos atores sociais.

A resposta afirma que os atores e as atrizes sociais apontam para esta ruptura como "uma insurreição religiosa", "um movimento para frente"; "uma ascensão para uma posição mais alta por parte daqueles que foram por séculos simbólica e politicamente relegados a um papel subordinado". Ademais, "aos olhos dos convertidos a nova situação religiosa: 'rompe a sucessão de opressão ideológica (e material) iniciada em tempo pré-coloniais... continuada durante a colonização espanhola e depois, perpetuada sob a jurisdição do Estado Argentino"34 (Rita SEGATO, 2007, p. 222, tradução livre).

No texto Religião e Feminismo Descolonial (Anete ROESE, 2015) já falando das rupturas das mulheres o patriarcalismo religioso faço referência a um politeísmo religioso das mulheres - como algo constituinte deste movimento de criação de igrejas e criação de religião pelas mulheres. As mulheres são, em princípio, infiéis ao monoteísmo. E sua infidelidade é insuportável ao patriarcalismo monoteísta, haja vista que ela dificulta a dominação. A infidelidade é insubordinação. Elas são infiéis porque precisam da religião para a vida cotidiana, precisam das "ervinhas", precisam da unção com óleo, da "aguinha da vida". Elas precisam disso porque exercitam a medicina caseira, cuidam, curam suas filhas, seus filhos e parentes. Em sua trajetória de autonomia religiosa elas misturam fontes espirituais/religiosas, fazem sínteses, sem o controle

34 A los ojos de los convertidos, la nueva situación religio- sa rompe la sucesión de opresión ideológica (y material) iniciada en tiem- pos pre-coloniales bajo el gobierno Inca, continuada durante la coloni- zación española y, después, perpetuada bajo la jurisdicción del Estado Argentino... 
teológico dogmático elas criam seu modo de fazer religião de acordo com as demandas cotidianas. Religião precisa fazer sentido para a vida pessoal. Elas querem a religião do vínculo, do afeto, da proximidade vincular, elas querem a comunidade e para tal criam vida comunitária. A ruptura delas com a opressão religiosa tem estes sentidos.

Através da conversão, então, os convertidos se adonam de um discurso legitimador que os subtrai do universo que os subordina e os dota de prestígio e autoridade moral. Deixam de se medir com referência aos valores oficiais que atribuem posições ao largo de hierarquias localmente estabelecidas de prestígio e influência. Em troca, passam a contar com uma nova referência de valor baseada no conhecimento direto da Bíblia, que agora os autoriza a julgar e avaliar por si mesmos blindando-os da submissão ancestral aos juízos das elites regionais (Rita SEGATO, 2007, p. 222, tradução livre). ${ }^{35}$

Podemos compreender o movimento das pastoras, como dos povos dos Andes, também como insurreição religiosa, movimento para frente, uma verdadeira ascensão. A 'desobediência' religiosa delas é benéfica para elas e seus grupos, suas comunidades, é a linguagem da rebelião, como diz Segato. Assim, rompem com uma lógica histórica de opressões que afirmam dogmaticamente a impossibilidade da autonomia das mulheres. Finalmente, não mais “obedecem' aos seus pastores, e criam um argumento teológico que funda e fundamenta sua ação de ruptura ao dizerem que tiveram um "chamado de Deus" para criarem sua própria igreja” (Anete ROESE, 2015, p. 1552). Assim elas derrubam o argumento bíblico, histórico, teológico e tradicional de que uma mulher não pode ser ordenada e não pode assumir o sacerdócio por ordem de Deus. Ora, elas determinam outra ordem e usam um argumento tão consistente, que é bíblica e teologicamente inquestionável, dizendo que Deus as visitou durante a noite e lhes fez uma revelação, dizendo-

35 A través de la conversión, entonces, los convertidos se adueñan de un discurso legitimador que los substrae del universo que los subordina y los dota de prestigio y autoridad moral. Dejan de medirse con referencia a los valo- res oficiales que atribuyen posiciones a lo largo de jerarquías localmente establecidas de prestigio e influencia. En cambio, pasan a contar con una nueva referencia de valor basada en el conocimiento directo de la Biblia, que ahora los autoriza a juzgar y evaluar por sí mismos, librándolos de la sumisión ancestral a los juicios de las élites regionales. 
-Ihes que havia um ministério para elas, como dito pela pastora Rosali e pelas pastoras já entrevistadas para outras pesquisas. Foi assim que Deus visitou Maria, por meio do anjo Gabriel, para lhe dizer que dela nasceria Jesus, o Salvador da humanidade. Deus tem autonomia para visitar quem desejar, isso é um forte argumento teológico, com sustentação no texto sagrado.

\section{ÚLTIMAS CONSIDERAÇÕES}

Na grande praça central de Encruzilhada do Sul está a catedral católica da cidade, nas quadras circundantes as igrejas evangélicas pentecostais e, abrindo mais e mais este quadrado de quadras, outras igrejas menores. À medida que nos afastamos do centro vamos encontrando as religiões guiadas por mulheres, as pequenas organizações religiosas e espirituais que atendem pequenos grupos - terreiros, pequenas igrejas, benzedeiras... São pequenos agrupamentos, no entanto numerosos em seu conjunto geral e, neste sentido, o significado deste 'movimento' não pode ser ignorado. Neste momento, não se trata, a meu ver, de fazer as comparações ou perguntas que a ciência convencional faria - , sobre a qualidade do discurso teológico, a racionalidade padrão masculina patriarcal ou a pergunta pela quantidade de fiéis que soma cada igreja em separado - perguntando pela eficácia numérica típica do padrão colonial capitalista, - justamente, porque são disfuncionais à lógica do capital. Aqui a pergunta, a pesquisa seguiu outras observações, referentes aos sentidos e valores inerentes a este tipo de movimento. Neste caso, as chaves de sentido apresentadas acima mostram o que significa a criação de igrejas, estas frentes religiosas alternativas, disfuncionais à lógica do capital religioso convencional, este modo de fazer religião das mulheres quando situamos este movimento em um contexto religioso, político e histórico.

En 'Hilando fino' (2010) Julieta Paredes esclarece que no feminismocomunitário quando propõe que a ideia de formar comunidade é uma política de superação do individualismo, ela se refere a qualquer forma de comunidade - rurais ou urbanas, religiosas, desportivas, culturais, políticas, de luta, educativas, de amizade, sexuais, agrícolas, de afeto, universitárias, etc... É possível construir comunidade desde qualquer 
grupo humano. A comunidade supera o par/casal, supera o agrupamento família tão convencional na moral colonial. Este é o sentido que está presente no 'movimento' das mulheres que fundam suas próprias igrejas, elas formam pequenas comunidades de convívio, apoio mútuo, cura... de superação do individualismo, pautadas na gestão vincular, considerando também o vínculo do humano com o divino.

O 'movimento' delas, das pastoras, não é politicamente organizado, mas não deixa de ser um movimento politicamente interessante pois envolve a desarticulação dominadora de muitas estruturas da modernidade colonial, patriarcal, com sua frente religiosa, midiática e empresarial. As pastoras - mulheres que fundam suas igrejas criam em sua volta um movimento que implica em outra proposta de vida espiritual. Agenciam e gerenciam um novo modo de viver a espiritualidade, um modo à moda doméstica, à moda da casa. Esta é também a política delas - sair das igrejas convencionais sem dar explicação, retiram-se, deixam os supostos grandes líderes órfãos de sua liderança. As comunidades e as pessoas que as seguem é gente que igualmente rompe com padrões religiosos de massa, padronizados, midiatizados, de discursos sofisticados e pouco efetivos para a vida cotidiana. Afinal, a religião destas mulheres é religião para a vida cotidiana. Em certo sentido a nova religião das mulheres é um movimento social, um caminho de viver bem, de Buen Vivir espiritual/religioso, pois retoma antigas convicções e modos de viver a espiritualidade totalmente integrada à vida - com vida comunitária, com apoio mútuo, com cuidados da saúde - pois a pastora também cuida da saúde de sua comunidade resgatando ou integrando nos cultos ou nos atendimentos cotidianos a atenção às necessidades físicas, psíquicas e espirituais.

\section{REFERÊNCIAS}

GUGLIELMONI, Rosane Aparecida de Souza. Religião e relações de gênero: Igrejas Evangélicas fundadas por mulheres na região industrial de Contagem, Minas Gerais. Dissertação (Mestrado). Programa de Pós-graduação em Ciências da Religião da Pontifícia Universidade Católica de Minas Gerais. Belo Horizonte, 2015.

PAREDES, Julieta; Comunidad Mujeres Creando Comunidad. Hilando fino desde el feminismocomunitario. La Paz: Melanie Cervantes, 2010. Disponível em: < https://sjlati- 
noamerica.files.wordpress.com/2013/06/paredes-julieta-hilando-fino-desde-el-feminismo-comunitario.pdf >.

PAREDES, Julieta C.; GUZMÁN, Adriana A.. El tejido de la rebeldia. Qué es el feminismo comunitário? Ed. Comunidad Mujeres Creando Comunidad. Moreno Artes Gráficas, La Paz, 2014.

ROESE, Anete. Religião e Feminismo Descolonial. Os protagonismos e os novos agenciamentos religiosos das mulheres no século XXI. Horizonte: Revista de estudos de teologia e ciências da religião (online). V.13. 1534-1558. http://periodicos.pucminas.br/ index.php/horizonte/issue/view/730/showToc, 2015.

ROESE, Anete. Vida sem religião: o caso da 'comunidade de mulheres' Noiva do Cordeiro". In: ROSADO, Maria José. Gênero, Feminismo e Religião. Sobre um campo em constituição. Rio de Janeiro: Garamond, p. 35-50, 2015.

SALGADO, Martha Patricia Castañeda. Etnografía Feminista. In: Investigación feminista Epistemología, metodología y representaciones sociales. México: UNAM, Centro de Investigaciones Interdisciplinarias en Ciencias y Humanidades: Centro Regional de Investigaciones Multidisciplinarias : Facultad de Psicología, 2012.

SCHULTZ, Adilson. Cartas de Jacobina e documentos do episódio Mucker. Protestantismo em Revista. Revista Eletrônica do Núcleo de Estudos e Pesquisa do Protestantismo (NEPP) da Escola Superior de Teologia Volume 02, 88-104, 2003.

SCHULTZ, Adilson. Problematização religiosa e histórica do episódio Mucker. Protestantismo em Revista. Revista Eletrônica do Núcleo de Estudos e Pesquisa do Protestantismo (NEPP) da Escola Superior de Teologia Volume 02, p. 16-23, 2003.

SEGATO, Rita Laura. Cambio religioso y des-etnificación: la expansión evangélica en los Andes Centrales de Argentina. In: La nación y sus otros. Raza, etnicidad y diversidad religiosa en tiempos de Políticas de la Identidad. Prometeo Libros: Ciudad Autónoma de Buenos Aires, p. 203-242, 2007.

SEGATO, Rita Laura. La guerra contra las mujeres. Madrid: Traficantes de Sueños, 2016. SILVA, Janine Targino da. Lideranças pentecostais femininas: um estudo sobre a fundação de igrejas pentecostais por mulheres em Nova Iguaçu - RJ. Dissertação (mestrado) - Universidade do Estado do Rio de Janeiro, Instituto de Filosofia e Ciências Humanas, 2010.

Submetido em: 10-12-2018

Aceito em: 13-12-2018 